\title{
Do woodland birds prefer to forage in healthy Eucalyptus wandoo trees?
}

Woodland birds and tree condition

\author{
T. L. Moore ${ }^{\mathrm{A}, \mathrm{C}}$, L. E. Valentine $\mathrm{A}^{\mathrm{A}, \mathrm{B}}$, M. D. Craig ${ }^{\mathrm{A}}$, G. E. StJ. Hardy and P. A. Fleming $^{\mathrm{A}}$ \\ ${ }^{A}$ Western Australian Centre of Excellence for Climate Change, Woodland and Forest Health, School \\ of Veterinary and Life Sciences, Murdoch University, Murdoch, WA 6150, Australia. \\ ${ }^{B}$ Present address: ARC Centre of Excellence for Environmental Decisions, School of Plant Biology, \\ University of Western Australia, Crawley, WA 6009, Australia. \\ CCorresponding author. Email: t.moore@murdoch.edu.au
}

Globally, many forests and woodlands are in decline. The marked loss of canopy foliage typical of these declines results in reduced foraging resources (e.g. nectar, pollen, and insects) and, subsequently, can reduce habitat quality for woodland birds. In south-west Western Australia, patches of Eucalyptus wandoo woodlands have shown a decline in condition since at least 2002. We investigated how changes in E. wandoo condition affect the woodland bird community. Foraging activities of three bird species were recorded for 20 sites in Dryandra State Forest and Wandoo Conservation Park either by conducting watches on focal trees ('sitting' method), or following individuals through the woodland ('following' method). Condition assessments of trees used by the birds were compared with those for trees available at the study site. Weebills (Smicrornis brevirostris; canopy insectivore) displayed preference for healthy trees (low amounts of canopy dieback), whereas rufous treecreepers (Climacteris rufa; bark-foraging insectivore) preferred trees with a higher proportion of dead branches. Yellowplumed honeyeaters (Lichenostomus ornatus; insectivore/nectarivore) foraged in older, larger E. wandoo trees having full canopies with few signs of tree decline. Tree declines, such as that happening in $E$. wandoo, alter the foraging resources and habitat available to woodland birds.

Additional keywords: foraging resources, habitat, tree condition, tree decline.

Received 8 February 2013, accepted 20 June 2013, published online

\section{Introduction}

Around Australia, woodland birds are showing population declines (Bennett and Watson 2011; Ford 2011). These changes have been linked with habitat change at the landscape and microhabitat scales (Watson et al. 2004b; Doerr et al. 2011). Climate change, land clearing, agriculture, and tree decline alter the woodlands and foraging resources for many guilds of birds, through alteration in the habitat quality and resources. Changes in habitat and foraging resources can alter the foraging behaviour and activity of birds (Calver and Dell 1998; Ford et al. 2001; McGinness et al. 2010; Doerr et al. 2011;

Ford 2011). For example, landscape alteration and a lack of connectivity between remaining fragments of native vegetation specifically restricts the foraging movement and behaviour of the brown treecreeper (Climacteris picumnus) in New South Wales (Doerr et al. 2011). On the other hand, the 
Publisher: CSIRO; Journal: ZO:Australian Journal of Zoology

Article Type: research-article; Volume: ; Issue: ; Article ID: ZO13045

DOI: 10.1071/ZO13045; TOC Head:

activities of birds can also influence habitat condition. For example, several studies have investigated the relationship between canopy decline and bell miners (Manorina melanophrys). Territorial bell miners exclude insectivorous birds that would usually control the populations of sap-feeding insects (e.g. psyllids) that feed on and defoliate eucalypts; the absence of insectivorous birds therefore contributes to tree decline (Stone 1996; Bradstock et al. 2005; Haywood and Stone 2011). The interactions between habitat and birds are most likely species-specific, and highlight the need to understand the specific habitat and feeding requirements of bird guilds (Radford et al. 2005) to predict their vulnerability to habitat changes.

Declines in tree condition and increases in tree mortality are occurring worldwide on a massive scale (Reid and Landsberg 2000; Close and Davidson 2004; Allen et al. 2010). Jurskis (2005) reviews many studies on decline episodes from all States around Australia, several occurring in each state. The causes of these declines are sometimes simple; however, in most cases, there appears to be a complex interplay of persistent abiotic and biotic damaging factors and mechanisms (Manion 1991). For example, fire suppression (Close et al. 2009), bell-miner activities (Stone 1996), climate change (Allen et al. 2010), and Phytophthora cinnamomi 'dieback' (Shea et al. 1983; Tippett et al. 1985) are all factors linked to tree declines. The slow progressive death of trees results in highly visible symptoms (Stone 1999), including the death of the upper portions of the tree foliage and loss of tree branches, resulting in an overall reduction in crown density (Stone 1999; Jurskis and Turner 2002; Jurskis 2005; Carnegie 2007; Davidson et al. 2007; Robinson 2008; Whitford et al. 2008). These changes in tree condition are likely to affect the activities of some bird guilds. For example, a study investigating the role of tuart (Eucalyptus gomphocephala) decline on birds identified that some feeding guilds may benefit from tree decline and the associated changes in resources, while other guilds are disadvantaged (Wentzel 2010). Long-term tree declines are, therefore, likely to result in changes in avifaunal diversity due to altered habitat quality and foraging resources (Loyn and Middleton 1980; Gorrod 2006).

Eucalyptus wandoo is a smooth-barked eucalypt endemic to Western Australia that has shown signs of episodic decline in condition since the 1960s, with the most recent decline commencing in 2002 (Hooper and Sivasithamparam 2005; Wandoo Recovery Group 2006). Decline in E. wandoo manifests as heterogeneous changes across the landscape, where declining trees can often be directly adjacent to apparently healthy trees, no tree mortality is evident, and the trees may also recover after a period of canopy loss (Brouwers et al. 2012). This decline is therefore unlike decline in jarrah (Eucalyptus marginata) in response to drought and high temperatures, where the whole canopy of trees is lost over a short period for patches of trees across the landscape (Matusick et al. 2012), and more closely resembles the responses of these trees to the presence of disease (Shea et al. 1983; Dakin et al. 2010).

The objective of the present study was to determine how the condition of $E$. wandoo trees influenced the tree selection by three common bird species (which are present in sufficient numbers to 
Publisher: CSIRO; Journal: ZO:Australian Journal of Zoology

Article Type: research-article; Volume: ; Issue: ; Article ID: ZO13045

DOI: 10.1071/ZO13045; TOC Head:

determine patterns of habitat preference). It was predicted that a declining canopy would lead to loss of food resources for several bird guilds (e.g. nectarivores, canopy-feeding insectivores and leaf gleaners). Epicormic growth is new flushes of growth in the canopy which is evident as trees recover (Landsberg 1985; Hobbs and Atkins 1988; Jurskis 2005). Epicormic growth may increase the foraging resources available to insectivores (e.g. weebills, Smicrornis brevirostris) (Arnold et al. 1987), as epicormic foliage may support more insects compared with established canopy (Landsberg and Wylie 1983; Landsberg 1988; Recher et al. 1996). Yellow-plumed honeyeaters (Lichenostomus ornatus) utilise foraging resources such as lerp, manna, and insects (Wilson and Recher 2001), which are found only in tree canopies and are likely to be absent for trees that have lost their canopy. E. wandoo trees showing a loss of canopy may therefore have fewer yellow-plumed honeyeaters foraging within them. Other guilds may benefit from an increase in foraging resources; for example, birds that make use of wood and dead branches as a foraging substrate (e.g. rufous treecreepers, Climacteris rufa) (Craig 2007) may benefit from the presence of trees in decline. The aim of this study was to test these predictions by comparing the condition of trees where birds were observed foraging with the condition of other trees available at the sites.

\section{Methods}

Site description

Study sites were located in E. wandoo-dominated woodlands in Dryandra State Forest $\left(32^{\circ} 48^{\prime} S\right.$, $116^{\circ} 53^{\prime} \mathrm{E}, 160 \mathrm{~km}$ south-east of Perth, Western Australia), and Wandoo Conservation Park (31 ${ }^{\circ} 54^{\prime} \mathrm{S}$, $116^{\circ} 27^{\prime} \mathrm{E}, 75 \mathrm{~km}$ east of Perth). E. wandoo woodlands once covered most of the wheatbelt region, but clearing for agriculture has resulted in only $40 \%$ of the original $E$. wandoo-dominated woodlands remaining (Mattiske Consulting Pty Ltd and Havel Land Consultants 1998; Doughty 2000). E. wandoo woodlands have an open canopy ( $\sim 30 \%$ canopy cover) with a patchy understorey of small shrubs usually < $1 \mathrm{~m}$ high, including Gastrolobium spp., Macrozamia riedlei and Xanthorrhoea preissii and a grassy herb layer (Yates and Hobbs 1997). Both reserves have histories of land clearing, stock grazing, harvesting (logging) and controlled fire management (Department of Conservation and Land Management 1980).

Observations were conducted at 20 sites in total, 10 each in Dryandra State Forest and Wandoo Conservation Park, with each site being a square 1-ha area. Sites were chosen using Vegmachine 2.0 (2010, CSIRO), which assesses changes in vegetation condition over a landscape through differences in its reflectance (Landsat imagery), classifying the vegetation as increasing, decreasing or stable. The times compared for this study were 1999 and 2009, as this was the period during which decline in $E$. wandoo had been noted (Mercer 2003; Whitford et al. 2008). Vegmachine was used to identify suitable sites at the desktop, and the exact location of sites and trees was determined by groundtruthing. 
Publisher: CSIRO; Journal: ZO:Australian Journal of Zoology

Article Type: research-article; Volume: ; Issue: ; Article ID: ZO13045

DOI: 10.1071/ZO13045; TOC Head:

\section{Surveying foraging woodland birds}

Bird activity was recorded in order to determine the correlation between tree condition and the use of trees by foraging birds. The three bird species observed were the nectarivorous/insectivorous yellowplumed honeyeater, and two insectivorous species: the weebill and the rufous treecreeper. The body size, diet and foraging ecology of these species differ and they utilise different parts of the $E$. wandoo trees (Table 1). These species are also commonly sighted in E. wandoo woodlands and therefore would be sighted often enough for adequate data collection and analysis. It was predicted that the foraging activities of each species would be influenced by different tree characteristics of the $E$. wandoo decline. Other species were recorded at these sites - striated pardalotes (Pardalotus striatus), red wattle birds (Anthochaera carunculata), and western wattlebirds (Anthochaera lunulata) - but sample sizes were inadequate for data analyses.

All observations were conducted by TLM using binoculars and recorded into a voice recorder for mornings (0600-1100 hours) and afternoons (1400-1600 hours) between July and October 2010. All 20 sites were visited each month (i.e. four surveys per site overall) and observations were carried out over eight days of each month to complete the recordings/data collection at all sites. The sites were returned to in random order to account for slight differences in the time of day.

The decline of $E$. wandoo woodlands is cyclic and patchy (Brouwers et al. 2012); no tree mortality is witnessed and healthy trees are often adjacent to declining trees. This made it difficult to work at a community level when, within a site, there is much variation in the condition of individual $E$. wandoo trees. In order to take this variation in E. wandoo condition into consideration when determining tree selection by the three bird species, the techniques observed the use of individual trees by birds. To ensure sufficient numbers of observations for analysis were made, two techniques were used for recording bird foraging and activity on individual trees. These methods were:

Method 1 The 'sitting' method entailed identifying which trees were either used or not used by birds during the survey period. The observer positioned herself in the centre of six E. wandoo trees (with a diameter $>20 \mathrm{~cm}$ ) closest to the centre of each site (hereafter called 'site' trees). Bird activity in these six trees was recorded over $20 \mathrm{~min}$. These trees were subsequently categorised as 'used' or 'unused' during this time. One 'use' of a tree is defined as an individual bird making one foraging attempt at a resource (i.e. flower, foliage, branch or trunk) within a single tree. Repeat observations of the same bird on the same tree within one observation period (20 min) were not included to avoid pseudoreplication. An 'unused' tree was defined as a site tree in which no foraging attempt was made by any bird (of any species) during any of the four observation periods made at each site.

Method 2 The 'following' method commenced with the observer starting in the centre of the six site trees and moving to the closest bird activity (movement or calls) that could be heard or observed. These birds were then followed on foot from tree to tree while foraging behaviour was observed and recorded continuously for 20 min or until the birds could no longer be seen (whichever occurred first). Hence, this method included not only the site trees, but also trees away from the centre point of each site. The trees that the birds used 
Publisher: CSIRO; Journal: ZO:Australian Journal of Zoology

Article Type: research-article; Volume: ; Issue: ; Article ID: ZO13045

DOI: 10.1071/ZO13045; TOC Head:

(hereafter referred to as 'selected trees') were marked and their location recorded with a GPS (Garmin eTrex

H) to return to for analysis. These selected trees were compared against the 'unused' site trees identified using Method 1.

The following variables were recorded for each bird observation:

(1) bird species;

(2) foraging height [six categories: ground, lower trunk (lower half), upper trunk (upper half), lower canopy (lowest third), mid canopy (middle third), upper canopy (upper third)];

(3) foraging substrate, or the type of food resource the individual was using (seven categories: flowers, foliage, live branches, hollows, dead branches, trunk/bark or leaf litter); and

(4) foraging manoeuvres (probe, glean, hang glean, hawk, sally, hover probe).

Foraging height and substrate were compared between species (pooling data across both survey methods) by Pearson's Chi-square analysis (Microsoft Excel 2010), with expected values calculated assuming that an equal proportion of individuals of each species used each foraging height/substrate category.

Tree condition characteristics

A range of tree characteristics were visually assessed for each tree (Table 2). The Whitford tree condition measure (healthy-declining: 1-6) (Whitford et al. 2008) and Grimes tree condition measure (healthy-declining: 5-0) (Grimes 1987) assign each tree a value commensurate with its condition, based on a pictorial scale. These semiqualitative measures incorporate epicormic growth, crown density, the proportion of dead branches and crown dieback in their assessments. The USDA tree condition assessment (Schomaker et al. 2007) (originally designed for pine trees in the USA using a range of tree condition measures, some of which can appropriately be transferred to eucalypt trees), includes visual estimates of crown density (\%), crown dieback (\%) and uncompacted live crown ratio (\%) (Table 2). Other tree condition measures that have been found relevant when assessing fauna habitat in eucalypts (Wentzel 2010) are the proportion of dead branches (\%) and epicormic growth (\%) (Table 2). Canopy height (m) was also measured for each individual tree using a digital vertex (Vertex III and Transponder T3, Haglöf Sweden AB). Tree litter cover (\%) was measured at the base of each tree using two 1- $\mathrm{m}^{2}$ quadrats. The percentage variables were converted to proportions and arcsine-square-root transformed (Zar 1998).

\section{Determining the correlations between tree characteristics and bird foraging}

Logistic regression (negative binomial - due to the high number of zeros in the data) using ' $\mathrm{R}$ ' 2.12 .1 and Tinn-R was carried out to determine whether birds were selective in their foraging trees. Analysis was carried out for bird species for which sufficient observations were available ('sitting' and 'following' survey methods analysed separately for yellow-plumed honeyeaters; ‘following' method only for weebills and rufous treecreepers). We compared trees that were used for foraging by birds 
Publisher: CSIRO; Journal: ZO:Australian Journal of Zoology

Article Type: research-article; Volume: ; Issue: ; Article ID: ZO13045

DOI: 10.1071/ZO13045; TOC Head:

(sitting method surveys: 'used' trees; following method surveys: 'selected' trees) with the characteristics of trees not witnessed as used (site trees not identified as used by each of the target species during the 20-min sitting method surveys: 'unused' trees; note different numbers of 'unused' trees for each species). Location (Dryandra State Forest or Wandoo National Park) was present in all models as a random factor. Independent variables included Whitford tree condition measure (1-6), Grimes tree condition measure (5-0), crown density, crown dieback, epicormic growth, uncompacted live crown ratio, proportion of dead branches, canopy height, and tree litter cover. A correlation matrix indicated that none of these factors were significantly autocorrelated $(r \geq 0.35, P>0.05)$.

Interpretation of the alternative logistic regression models was carried out by Akaike Information Criterion (AIC), corrected for small sample size ( $\mathrm{AIC}_{\mathrm{c}}$ ). In total, 211 models were created for each dependent variable using various combinations of all the tree characteristics. The top models $\left(\Delta \mathrm{AIC}_{\mathrm{c}}<\right.$ 2) were considered a plausible fit for the data (Quinn and Keough 2002) and are considered well supported models to describe the dataset. The $\mathrm{AIC}_{\mathrm{c}}$ model weight $\left(w_{i}\right)$ was calculated for each of the top models: $w_{i}$ values indicate the likelihood that each model is the best model of the model set to explain the dataset. We calculated a standardised $\beta$ coefficient (indicating how much each parameter contributed to the model) and $P$ values for each parameter in the model. The standardised $\beta$ coefficients are the coefficients obtained if you had first standardised all of your variables to a mean of 0 and a standard deviation of 1 ; thus, the standardised $\beta$ value allows direct assessment of the relative contribution of each independent variable (i.e. tree and habitat characteristics) in the prediction of the dependent variable.

\section{Likelihood ratio test}

A likelihood ratio test assesses the fit of a model. The test compares the alternate and null models to produce a log-likelihood ratio statistic (LLc) and degrees of freedom (d.f.). In this case, models that included tree characteristics were compared with models without these tree characteristics included (the null-model) to determine whether the former were a better fit to the data. The $P$ value is then determined from the binomial distribution using the LLc and d.f. and the alternate model is proven or rejected in place of the null model.

\section{Results}

The three bird species (yellow-plumed honeyeaters, weebills, and rufous treecreepers) each used different parts of the trees (heights: Fig. 1a): yellow-plumed honeyeaters and weebills foraged in the mid-upper canopy, while rufous treecreepers more commonly foraged lower in the canopy and on the trunk more than the other species. They also differed in their use of foraging resources (substrates: Fig. 1b): live branches and foliage were the common foraging resources used by yellow-plumed honeyeaters and weebills, while rufous treecreepers foraged on branches more than the other two species. The foraging manoeuvres of each of the three common bird species were relatively consistent, 
Publisher: CSIRO; Journal: ZO:Australian Journal of Zoology

Article Type: research-article; Volume: ; Issue: ; Article ID: ZO13045

DOI: 10.1071/ZO13045; TOC Head:

with $>95 \%$ of the observations of yellow plumed honeyeaters and weebills recorded as gleaning, and $>95 \%$ of observations of rufous treecreepers recorded as probing bark.

Live branches ( $n=205$ observations) and foliage ( $n=271$ observations) were the common foraging resources used by yellow-plumed honeyeaters (Fig. $1 b$ ). Dead branches ( $n=9$ observations), flowers ( $n=9)$, tree litter cover $(n=20)$ and trunk/bark $(n=54)$ were also used. For each survey method, a single well supported model best explained the differences between trees that were not used, and trees that were used/selected by yellow-plumed honeyeaters. The adjusted $R^{2}$ value for the 'sitting' survey method was only 0.044 , suggesting that there was poor explanatory power, probably because there were only $n=12$ selected trees (compared with $n=108$ unused site trees) for this method. For the 'following' survey method ( $n=73$ selected trees compared with $n=108$ unused site trees), the best model indicated that yellow-plumed honeyeaters preferred to forage in taller trees that had a larger proportion of crown (uncompacted live crown ratio), with some dead branches (positive relationships with the proportion of dead branches) but overall minimal crown loss (negative relationships with crown dieback) (Table 3). Yellow-plumed honeyeaters therefore showed preference for larger E. wandoo trees with minimal canopy loss.

The insectivorous weebill primarily used foliage ( $n=116$ observations) and, to a lesser extent, live branches $(n=34)$, tree litter cover $(n=2)$, dead branches $(n=2)$ and flowers $(n=9)$ for foraging resources (Fig. 1b). A single model described data from the 'following' survey method ( $n=31$ selected trees compared with $n=118$ unused site trees), which included positive correlations with uncompacted live crown ratio, canopy height, proportion of dead branches, and epicormic growth, but a negative correlation with crown dieback (Table 3). This indicates that weebills foraged in taller $E$. wandoo trees (with only a small amount of canopy loss or epicormic growth present).

Rufous treecreepers used dead branches ( $n=109$ observations), trunk/bark $(n=22)$, foliage $(n=2)$, tree litter cover $(n=4)$ and live branches $(n=13)$ for foraging substrates (Fig. 1b). Using the 'following' survey method ( $n=16$ selected trees compared with $n=120$ unused site trees), there was a positive correlation between trees used by rufous treecreepers and uncompacted live crown ratio, canopy height, and proportion of dead branches, but negative correlations with crown dieback and epicormic growth. Treecreepers were therefore using taller trees with larger canopies but also more dead branches. Although the number of selected trees was small, the adjusted $R^{2}$ for this model was 0.463 .

Likelihood ratio tests demonstrate that the models including the tree characteristics were a better fit to the data $(P<0.05)$ than the null models (without tree characteristics) (Table 3$)$. The models including the tree characteristics therefore had better explanatory power to describe the selection of $E$. wandoo trees by these bird species than the models without tree characteristics. 
Publisher: CSIRO; Journal: ZO:Australian Journal of Zoology

Article Type: research-article; Volume: ; Issue: ; Article ID: ZO13045

DOI: 10.1071/ZO13045; TOC Head:

Several tree condition measures and habitat features were not included in the top logistic regression models. These included Whitford tree condition, crown density, and tree litter cover. These results indicate that these measures were not strongly predictive of the activity of these three focal bird species in E. wandoo woodlands. Common variables in the best models (canopy height, crown dieback, uncompacted live crown ratio, proportion of dead branches, and epicormic growth) better described the dataset.

\section{Discussion}

It is important to identify factors that are likely to detrimentally influence woodland birds, as many woodland birds have been noted as currently undergoing serious population declines (Bennett and Watson 2011; Ford 2011). This includes the yellow-plumed honeyeater and rufous treecreeper, which have declined across their range in the farming region of Western Australia (Ford et al. 2001). Understanding the effects of woodland habitat and degradation upon birds is therefore an important aspect of managing these landscapes (Maron et al. 2011). This is particularly true for birds that are commonly found in the woodlands, as they may be the first to demonstrate observable relationships with the changes in habitat. The present study demonstrated that the relative size and density of the canopy influences the selection of $E$. wandoo trees by foraging birds. Canopy height and canopy size (i.e. uncompacted live crown ratio) contributed to models distinguishing between trees used by birds and those not observed as used. However, the condition of the trees was also an important factor, with the presence of dead branches, epicormic growth and crown dieback contributing to models describing tree selection by foraging birds. Generally, E. wandoo trees chosen by birds were taller and showed fewer signs of complete canopy loss, although dead branches were present in trees used as foraging resources by all three focal bird species. We discuss the results of this study in the context of the decline of tree condition in general.

Yellow-plumed honeyeaters, rufous treecreepers and weebills were each more likely to forage in larger trees with a higher canopy to trunk ratio. Similarly, yellow-plumed honeyeaters have previously been shown to prefer older, larger trees (Wilson and Recher 2001). Most observations of foraging by yellow-plumed honeyeaters were in mid- to upper-canopy on foliage and branches. These birds were rarely observed foraging on flowers, which supports previous studies showing that this principally insectivorous species forages on flowers $<10 \%$ of the time (Recher and Davis 1998; Wilson and Recher 2001). Weebills largely foraged amongst foliage and branches, but were also observed foraging on flowers where these insectivores were likely retrieving insects. Although Arnold (1988) and Watson et al. (2004a) recorded positive relationships between the abundance of weebills and dense overstorey canopy, we recorded some preference for trees with dead branches, which may indicate some natural senescence of larger/older trees, or that early decline of $E$. wandoo canopy may be beneficial to weebills. Rufous treecreepers create territories in woodlands with larger, older trees possessing hollows (Luck 2002), which supports the positive relationships between treecreepers and 
Publisher: CSIRO; Journal: ZO:Australian Journal of Zoology

Article Type: research-article; Volume: ; Issue: ; Article ID: ZO13045

DOI: 10.1071/ZO13045; TOC Head:

canopy height and uncompacted live crown ratio in the current study. Structurally complex, larger

eucalypt trees, such as E. wandoo, support more invertebrate prey (Majer 1985; Recher et al. 1996)

and would provide a greater range of foraging resources than smaller trees.

We had predicted that insectivores were more likely to make use of epicormic growth in E. wandoo since invertebrate abundance is higher in epicormic growth of various eucalypt species compared with older leaves (Landsberg and Wylie 1983; Marsh and Adams 1995). However, the relationships with epicormic growth were not strong, and in the case of rufous tree creepers were actually negative. While rufous treecreepers forage more commonly for invertebrates on branches and dead wood (Craig 2007), weebills and yellow-plumed honeyeaters use the invertebrate resources in canopy foliage and around live branches (Arnold et al. 1987; Wilson and Recher 2001). Robinson and Holmes (1984) outlined that the structure of the foliage will not only influence the abundance of invertebrate prey but also bird foraging behaviour (e.g. hawking or hovering). Dense new foliage (epicormic growth) may therefore be nutritionally superior, but may be a difficult foraging substrate for birds to access. Future studies quantifying the invertebrate prey in declining and healthy $E$. wandoo trees (particularly in and around epicormic growth) would indicate whether the observed relationships with bird foraging activities can be explained by invertebrate abundance.

We predicted that species that use dead wood would be more likely to benefit from decline in tree condition, which results in more dead branches in the canopy and on the woodland floor (Landsberg 1985; Hooper and Sivasithamparam 2005; Jurskis 2005; Davidson et al. 2007). Dead branches can benefit birds via the provision of invertebrate prey, and perching branches from which to pounce upon or sally for prey (Wentzel 2010). All three birds surveyed in the present study showed a positive correlation with the presence of dead branches. Rufous treecreepers commonly foraged on dead wood and trunk (i.e. bark); they were rarely observed on the ground. Similarly, Craig (2007) found that rufous treecreepers foraged on the ground only $7 \%$ of the time, compared with $83 \%$ of observations on standing vegetation and $9 \%$ on fallen logs and stumps. Yellow-plumed honeyeaters use dead branches not only for bark probing, but as perches to take off from to hover, snatch or hawk for invertebrate prey (Wilson and Recher 2001). Weebills primarily feed on insects within the foliage (Arnold et al. 1987); their relationship with dead branches may be linked with preference for older $E$. wandoo trees that naturally have more dead branches.

Both positive and negative correlations between yellow-plumed honeyeaters foraging and canopy height were recorded for the two survey methods. These conflicting results may be a consequence of the naturally open canopy of E. wandoo (Mercer 1991; Cousin and Phillips 2008) that is highly variable in the percentage of crown density, even between healthy trees. Differences in the results between the two survey methods may also reflect the dissimilar numbers of trees included in each. Remaining in the same location (the 'sitting' method) meant that there was time where the observer was watching focal trees but no bird activity was occurring. By contrast, the 'following' method 
Publisher: CSIRO; Journal: ZO:Australian Journal of Zoology

Article Type: research-article; Volume: ; Issue: ; Article ID: ZO13045

DOI: 10.1071/ZO13045; TOC Head:

guarantees more data (as demonstrated by the higher number of observations on a higher number of trees). As a caveat, however, the 'following' method does not clearly identify when trees were not being used by birds.

Several tree characteristics and habitat features (Whitford tree condition measure, crown density, tree litter cover) were not included in the best models. A lack of inclusion of crown density in any of the best models may be a consequence of the open canopy of E. wandoo (Mercer 1991; Cousin and Phillips 2008) that has highly variable crown density values between trees. As the three focal bird species are largely canopy dwelling (Arnold et al. 1987; Wilson and Recher 2001; Craig 2007), it is not surprising that tree litter cover was not strongly correlated with any of the species’ tree selection.

Tree condition characteristics were included in the best models describing the foraging activities of birds, suggesting that the condition of $E$. wandoo plays a role in the choice of trees for foraging activities by these woodland bird species. The patchy nature of the decline means that birds would not have to travel large distances to find the foraging resources they require, whether the resources result from healthy or declining $E$. wandoo trees. A more widespread long-term decline that results in tree mortality or at least severe loss of canopy, in addition to a warming climate and fewer rainfall events has the potential to significantly affect bird populations. Without understanding the aetiology of $E$. wandoo decline, it is difficult to predict the long-term effects of changes in tree condition upon birds.

\section{Acknowledgements}

We acknowledge funding for this project from Holsworth Research Endowment, State Centre for Excellence of Climate Change, Woodland and Forest Health, Birds Australia - Stuart Leslie Research Award, Birds Australia - Western Australia and Murdoch University. Field assistance was gratefully received from Tegan Douglas and Kathryn Napier. This work was carried out in accordance with Murdoch University’s Animal Ethics Committee (R2270/09) and Department of Environment and Conservation permits (Reg. 17 SF007629).

\section{References}

<jrn>Allen, C. D., Macalady, A. K., Chencouni, H., Bachelet, D., Mc Dowell, N., Vennetier, M., Kitzberger, T., Rigling, A., Breshears, D. D., Hogg, E. H., Gonzalez, P., Fensham, R., Zhang, Z., Casto, J., Demidova, N., Lim, J. H., Allard, G., Running, S. W., Semerci, A., and Cobb, A. (2010). A global overview of drought and heat-induced tree mortality reveals emerging climate change risks for forests. Forest Ecology and

Management 259, 660-684. doi:10.1016/j.foreco.2009.09.001</jrn>

$<$ jrn>Arnold, G. W. (1988). The effects of habitat structure and floristics on the densities of bird species in wandoo woodland. Australian Wildlife Research 15, 499-510. doi:10.1071/WR9880499</jrn>

<jrn>Arnold, G. W., Maller, R. A., and Litchfield, R. (1987). Comparison of bird populations in remnants of wandoo woodland and in adjacent farmland. Australian Wildlife Research 14, 331-341.

doi:10.1071/WR9870331</jrn> 
Publisher: CSIRO; Journal: ZO:Australian Journal of Zoology

Article Type: research-article; Volume: ; Issue: ; Article ID: ZO13045

DOI: 10.1071/ZO13045; TOC Head:

<jrn>Bennett, A. F., and Watson, D. M. (2011). Declining woodland birds - is our science making a difference?

Еmu 111, i-iv. doi:10.1071/MUv111n1 ED $<$ jrn>

<jrn>Bradstock, R. A., Bedward, M., Gill, A. M., and Cohn, J. S. (2005). Which moasic? A landscape ecological approach for evaluating interactions between fire regimes, habitats and animals. Wildlife Research 32, 409423. doi:10.1071/WR02114</jrn>

<jrn>Brouwers, N. C., Mercer, J., Lyons, T., Poot, P., Veneklaas, E., and Hardy, G. (2012). Climate and landscape drivers of tree decline in a Mediterranean ecoregion. Ecology and Evolution 3, 67-79. doi:10.1002/ece3.437</jrn>

$<$ jrn>Calver, M. C., and Dell, J. (1998). Conservation status of mammals and birds in southwestern Australian forests. I. Is there evidence of direct links between forestry practices and species decline and extinction? Pacific Conservation Biology 4, 296-314.</jrn>

<jrn>Carnegie, A. J. (2007). Forest health condition in New South Wales, Australia, 1996-2005. II. Fungal damage recorded in eucalypt plantations during forest health surveys and their management. Australasian Plant Pathology 36, 225-239. doi:10.1071/AP07021</jrn>

$<$ jrn>Close, D. C., and Davidson, N. J. (2004). Review of rural tree decline in a changing Australian climate. Tasmanian Forests 15, 1-18. </jrn>

<jrn>Close, D. C., Davidson, N. J., Johnson, D. W., Abrams, M. D., Hart, S. C., Lunt, I. D., Archibald, R. C., Horton, B., and Adams, M. A. (2009). Premature decline of Eucalyptus and altered ecosystem processes in the absence of fire in some Australian forests. Botanical Review 75, 191-202. doi:10.1007/s12229-009-9027$\mathrm{y}</ \mathrm{jrn}>$

$<$ jrn>Cousin, J. A., and Phillips, R. D. (2008). Habitat complexity explains species-specific occupancy but not species richness in a Western Australian woodland. Australian Journal of Zoology 56, 95-102. doi:10.1071/ZO07065</jrn>

$<$ jrn>Craig, M. D. (2007). The ecology of the rufous treecreeper in the jarrah forest of south-western Australia and implications for its conservation and management. Australian Journal of Ecology 55, 41-48.</jrn>

$<$ jrn>Dakin, N., White, D., Hardy, G. E. S. J., and Burgess, T. I. (2010). The opportunistic pathogen,

Neofusicoccum australe, is responsible for crown dieback of peppermint (Agonis flexuosa) in Western Australia. Australasian Plant Pathology 39, 202-206. doi:10.1071/AP09085</jrn>

<jrn>Davidson, N. J., Close, D. C., Battaglia, M., Churchill, K. M. O., Watson, T., Bruce, J. (2007). Eucalypt health and agricultural land management within bushland remnants in the Midlands of Tasmania, Australia. Biological Conservation 139, 439-446. doi:10.1016/j.biocon.2007.07.019</jrn>

< other>Department of Conservation and Land Management (1980). Dryandra Management Plan. Department of Conservation and Land Management, Western Australia.</other>

$<$ jrn>Doerr, V. A. J., Doerr, E. D., Davies, M. J. (2011). Dispersal behaviour of brown treecreepers predicts functional connectivity for several other woodland birds. Emu 111, 71-83. doi:10.1071/MU09118</jrn> 
Publisher: CSIRO; Journal: ZO:Australian Journal of Zoology

Article Type: research-article; Volume: ; Issue: ; Article ID: ZO13045

DOI: 10.1071/ZO13045; TOC Head:

<bok>Doughty, R. W. (2000). ‘The Eucalyptus. A Natural and Commercial History of the Gum Tree.' (The John Hopkins University Press: Baltimore $>$ ) $<$ /bok $>$

$<$ jrn>Ford, H. A. (2011). The causes of decline of birds of eucalypt woodlands: advances in our knowledge over the last 10 years. Emu 111, 1-9. doi:10.1071/MU09115</jrn>

$<$ jrn>Ford, H. A., Barrett, G. W., Saunders, D., and Recher, H. F. (2001). Why have birds in the woodlands of southern Australia declined? Biological Conservation 97, 71-88. doi:10.1016/S0006-3207(00)00101-4</jrn>

$<$ jrn>Gorrod, E. (2006). Evaluating the ecological and operational basis of vegetation condition assessments. Ecological Management \& Restoration 7(S1), S80. doi:10.1111/j.1442-8903.2006.298_5.x</jrn>

<bok>Grimes, R. F. (1987). Crown assessment of natural spotted gum (Eucalyptus maculata) and ironbark

(Eucalyptus fibrosa, Eucalyptus depranophylla) forest. Queensland Department of Forestry.</bok>

<jrn>Haywood, A., and Stone, C. (2011). Mapping eucalypt forest susceptible to dieback associated with bell miners (Manorina melanophys) using laser scanning, SPOT 5 and ancillary topographical data. Ecological Modelling 222, 1174-1184. doi:10.1016/j.ecolmodel.2010.12.012</jrn>

$<$ jrn>Hobbs, R. J., and Atkins, L. (1988). Effect of disturbance and nutrient addition on native and introduced annuals in plant communities in the Western Australian wheatbelt. Australian Journal of Ecology 13, 171179. doi:10.1111/j.1442-9993.1988.tb00966.x</jrn>

$<$ jrn>Hooper, R. J., and Sivasithamparam, K. (2005). Characterisation of damage and biotic factors associated with the decline of Eucalyptus wandoo in south western Western Australia. Canadian Journal of Forest Research 35, 2589-2602. doi:10.1139/x05-162</jrn>

$<$ jrn> Jurskis, V. (2005). Eucalypt decline in Australia and a general concept of tree decline and dieback. Forest Ecology and Management 215, 1-20. doi:10.1016/j.foreco.2005.04.026</jrn>

$<$ jrn>Jurskis, V., and Turner, J. (2002). Eucalypt dieback in eastern Australia: a simple model. Australian Forestry 65, 87-98. doi:10.1080/00049158.2002.10674859 $</ j r n>$

$<$ jrn>Landsberg, J. (1985). Drought and dieback of rural eucalypts. Australian Journal of Ecology 10, 87-90. doi:10.1111/j.1442-9993.1985.tb00868.x $<$ jrn $>$

<jrn>Landsberg, J. (1988). Dieback of rural eucalypts: tree phenology and damage caused by leaf-feeding insects. Australian Journal of Ecology 13, 251-267. doi:10.1111/j.1442-9993.1988.tb00973.x</jrn>

<jrn>Landsberg, J., and Wylie, F. R. (1983). Water stress, leaf nutrients and defoliation: a model of dieback of rural eucalypts. Australian Journal of Ecology 8, 27-41. doi:10.1111/j.1442-9993.1983.tb01516.x</jrn>

$<$ edb>Loyn, R. H., and Middleton, W. G. D. (1980). Eucalypt decline and wildlife in rural areas. In 'Eucalypt Dieback in Forests and Woodlands'. (Eds K. M. Old, G. A. Kile, and C. P. Ohmart.) pp. 95-111. (CSIRO: Melbourne. $)</$ edb $>$

$<$ jrn>Luck, G. W. (2002). The habitat requirements of the rufous treecreeper (Climateris rufa). 1. Preferential habitat use demonstrated at multiple spatial scales. Biological Conservation 105, 383-394.

doi:10.1016/S0006-3207(01)00222-1</jrn> 
Publisher: CSIRO; Journal: ZO:Australian Journal of Zoology

Article Type: research-article; Volume: ; Issue: ; Article ID: ZO13045

DOI: 10.1071/ZO13045; TOC Head:

<other>Majer, J. D. (1985). Invertebrate studies in disturbed and pristine habitats of Dryandra State Forest.

Forests Department of Western Australia No. 80.</other>

<bok>Manion, P. D. (1991). 'Tree Disease Concepts.' (Prentice Hall: Englewood Cliffs, NJ.)</bok>

<jrn>Maron, M., Main, A., Bowen, M., Howes, A., Kath, J., and Pillette, C. (2011). Relative influence of habitat modification and interspecific competition on a woodland bird assemblage in eastern Australia. Emu 111, 4051. doi:10.1071/MU09108 $</$ jrn $>$

<jrn>Marsh, N. R., and Adams, M. A. (1995). Decline of Eucalyptus tereticornis near Bairnsdale, Victoria: insect herbivory and nitrogen fractions in sap and foliage. Australian Journal of Botany 43, 39-50. doi:10.1071/BT9950039 $<$ /jrn>

<other>Mattiske Consulting Pty Ltd and Havel Land Consultants (1998). Vegetation mapping in the south west of Western Australia. Prepared for Environment Australia and the Department of Conservation and Land Management.</other $>$

<jrn>Matusick, G., Ruthrof, K. X., and Hardy, G. E. S. J. (2012). Drought and heat triggers sudden and severe dieback in a dominant Mediterranean-type woodland species. Open Journal of Forestry 2, 183-186. doi:10.4236/ojf.2012.24022</jrn>

<jrn>McGinness, H. M., Arthur, A. D., and Reid, J. R. W. (2010). Woodland bird declines in the MurrayDarling Basin: are there links with floodplain change? The Rangeland Journal 32, 315-327. $\underline{\underline{\text { doi:10.1071/RJ10016}}</ j r n>~}$

<other>Mercer, J. (1991). The decline of Eucalyptus wandoo Blakely in the Western Australian wheatbelt area. B.Sc.(Honours) Thesis, School of Biological Sciences, Murdoch University, Perth.</other>

<other>Mercer, J. (2003). Survey of Eucalyptus wandoo decline. A report on wandoo decline in the Western Australian wheatbelt on behalf of the Department of Conservation and Land Management. Department of Conservation and Land Management, Perth.</other>

<jrn>Pike, D. A., Peterman, K. S., and Exum, J. H. (2008). Habitat structure influences the presence of sand skinks (Plestiodon reynoldsi) in altered habitats. Wildlife Research 35, 120-127. doi:10.1071/WR07119</jrn> $<$ edb>Podger, F. D. (1980). Some difficulties in the diagnosis of drought as a cause of dieback. In 'Eucalypt Dieback in Forests and Woodlands.' (Eds K. M. Old, G. A. Kile, and C. P. Ohmart.) pp. 167-173. (CSIRO: Melbourne. $)<$ edb $>$

$<$ bok>Quinn, G. P., and Keough, M. J. (2002). 'Experimental Design and Data Analysis for Biologists.'

(Cambridge University Press: Cambridge.)</bok>

<jrn>Radford, J. Q., Bennett, A. F., and Cheers, G. J. (2005). Landscape-level thresholds of habitat cover for woodland-dependant birds. Biological Conservation 124, 317-337. doi:10.1016/j.biocon.2005.01.039</jrn>

$<$ jrn>Recher, H. F., and Davis, W. E. (1998). The foraging profile of a wandoo woodland avifauna in early spring. Australian Journal of Ecology 23, 514-527. doi:10.1111/j.1442-9993.1998.tb00762.x </jrn> 
Publisher: CSIRO; Journal: ZO:Australian Journal of Zoology

Article Type: research-article; Volume: ; Issue: ; Article ID: ZO13045

DOI: 10.1071/ZO13045; TOC Head:

$<$ jrn>Recher, H. F., Majer, J. D., and Ganesh, S. (1996). Eucalypts, arthropods and birds: on the relation between foliar nutrients and species richness. Forest Ecology and Management 85, 177-195. doi:10.1016/S0378$\underline{1127(96) 03758-9}</$ jrn $>$

<edb>Reid, N., and Landsberg, J. (2000). Tree decline in agricultural landscapes: what we stand to lose. In ‘Temperate Eucalypt Woodlands in Australia. Biology Conservation, Management and Restoration’. (Eds R. J. Hobbs, and C. J. Yates.) pp. 127-166. (Surrey Beatty: Sydney.)</edb>

$<$ jrn>Robinson, R. (2008). Forest health surveillance in Western Australia: a summary of major activities from 1997 to 2006. Australian Forestry 71, 202-211. doi:10.1080/00049158.2008.10675036</jrn>

$<$ jrn>Robinson, S. K., and Holmes, R. T. (1984). Effects of plant species and foliage structure on the foraging behavior of forest birds. The Auk 101, 672-684. doi:10.2307/4086894</jrn>

<bok>Schomaker, M. E., Zarnoch, S. J., Bechtold, W. A., Latelle, D. J., Burkman, W. G., and Cox, S. M. (2007). Crown-condition classification: a guide to data collection and analysis. United States Department of Agriculture, Forest Service, Southern Research Station, Asheville, NC.</bok>

<jrn>Shea, S. R., Shearer, B. L., Tippett, J. T., and Deegan, P. M. (1983). Distribution, reproduction, and movement of Phytophthora cinnamomi on sites highly conducive to jarrah dieback in south Western Australia. Plant Disease 67, 970-973. doi:10.1094/PD-67-970</jrn>

<eref>StatSoft Inc (2007). STATISTICA (data analysis software system), version 8.0. Available at: www.statsoft.com. Tulsa OK, USA.</eref>

$<$ jrn>Stone, C. (1996). The role of psyllids (Hemiptera: Psyllidae) and bell miners (Manorina melanophrys) in canopy dieback of Sydney blue gum (Eucalyptus saligna Sm.). Australian Journal of Ecology 21, 450-458. doi:10.1111/j.1442-9993.1996.tb00631.x $</ j r n>$

$<$ jrn>Stone, C. (1999). Assessment and monitoring of decline and dieback of forest eucalypts in relation to ecologically sustainable forest management; a review with a case study. Australian Forestry 62, 51-58. doi:10.1080/00049158.1999.10674763</jrn>

<jrn>Tippett, J. T., Hill, T. C., and Shearer, B. L. (1985). Resistance of Eucalyptus spp. to invasion of Phytophthora cinnamoni. Australian Journal of Botany 33, 409-418. doi:10.1071/BT9850409</jrn>

$<$ jrn>Vernes, K., Castellano, M., and Johnson, C. N. (2001). Effects of season and fire on the diversity of hypogeous fungi consumed by a tropical mycophagous marsupial. Journal of Animal Ecology 70, 945-954. doi:10.1046/j.0021-8790.2001.00564.x $</ j r n>$

$<$ other>Wandoo Recovery Group (2006). Wandoo crown decline. Action Plan. Department of Environment and Conservation, Perth.</other $>$

<jrn>Watson, D. M., Watson, A., Paull, D., and Freudenberger, D. (2004a). Woodland fragmentation is causing the decline of species and functional groups of birds in southeast Australia. Pacific Conservation Biology 8, $261-270 .</ j r n>$ 
Publisher: CSIRO; Journal: ZO:Australian Journal of Zoology

Article Type: research-article; Volume: ; Issue: ; Article ID: ZO13045

DOI: 10.1071/ZO13045; TOC Head:

<jrn>Watson, J. E. M., Whittaker, R. J., and Dawson, T. P. (2004b). Habitat structure and proximity to forest

edge affect the abundance and distribution of forest-dependant birds in tropical coastal forests of southeastern Madgascar. Biological Conservation 120, 311-327. doi:10.1016/j.biocon.2004.03.004</jrn>

<other>Wentzel, J. J. (2010). Is tuart (Eucalyptus gomphocephala) decline detrimental for fauna? Ph.D. Thesis,

Murdoch University, Perth.</other $>$

<other>Whitford, K., Manning, L., and Wills, A. (2008). Wandoo crown condition. Report of wandoo crown

decline surveys, 2008. Department of Environment and Conservation and Wandoo Recovery Group. $</$ other $>$

$<$ jrn>Wilson, K., and Recher, H. F. (2001). Foraging ecology and habitat selection of the yellow-plumed

honeyeater, Lichenostomus ornatus, in a Western Australian woodland: implications for conservation. Emu

101, 89-94. doi:10.1071/MU00068 $</ j r n>$

<jrn>Yates, C. J., and Hobbs, R. J. (1997). Temperate eucalypt woodlands: a review of their status, processes

threatening their persistence and techniques for restoration. Australian Journal of Botany 45, 949-973.

doi:10.1071/BT96091</jrn>

<bok>Zar, J. H. (1998). ‘Biostatistical Analysis.’ 4th edn. (Prentice Hall: New Jersey.)</bok>

Handling Editor: Phillip Cassey

Fig. 1. Numbers of observations of weebills (Smicrornis brevirostris; $n=164$ observations), rufous treecreepers (Climacteris rufa; $n=150$ observations) and yellow-plumed honeyeaters (Lichenostomus ornatus; $n$ $=566$ observations) broken down according to $(a)$ foraging height, or $(b)$ foraging substrate. Data collected using both the 'sitting' and 'following' survey methods are pooled. Significance of Chi-square tests are indicated as *, $P<0.05$; **, $P<0.01$; ***, $P<0.005$.

Table 1. Characteristics of the three focal bird species examined in this study (Pike et al. 2008; Vernes et al. 2001) and the foraging substrate and tree health characteristics predicted to influence each

Sufficient observations were made for analysis of yellow-plumed honeyeaters (both survey methods), weebills ('following' method only) and rufous treecreeper ('following' method only)

\begin{tabular}{|c|c|c|c|c|c|c|c|}
\hline \multirow[t]{2}{*}{ Bird species } & \multirow{2}{*}{$\begin{array}{l}\text { Body } \\
\text { size } \\
(\mathrm{cm})\end{array}$} & \multirow[t]{2}{*}{$\begin{array}{l}\text { Feeding } \\
\text { guild }\end{array}$} & \multirow{2}{*}{$\begin{array}{l}\text { Preferred } \\
\text { foraging } \\
\text { resource }\end{array}$} & \multicolumn{2}{|c|}{$\begin{array}{c}\text { Influence of tree condition characteristics on } \\
\text { foraging activities }\end{array}$} & \multicolumn{2}{|c|}{$\begin{array}{l}\text { No. of observations } \\
\text { (individual trees) }\end{array}$} \\
\hline & & & & Predicted & Observed correlations & $\begin{array}{l}\text { 'Sitting' } \\
\text { method }\end{array}$ & $\begin{array}{l}\text { 'Following } \\
\text { method }\end{array}$ \\
\hline $\begin{array}{l}\text { Lichenostomus } \\
\text { ornatus (yellow- } \\
\text { plumed honeyeater) }\end{array}$ & $15-17$ & $\begin{array}{l}\text { Insectivore, } \\
\text { nectarivore }\end{array}$ & $\begin{array}{l}\text { Foliage, } \\
\text { flowers }\end{array}$ & $\begin{array}{l}\text { Crown density, } \\
\text { crown } \\
\text { dieback, } \\
\text { epicormic } \\
\text { growth }\end{array}$ & $\begin{array}{l}\text { Taller trees with healthier, } \\
\text { relatively larger proportion } \\
\text { canopy, and trees that had } \\
\text { more leaf litter at their bases } \\
\text { (Whitford tree condition } \\
\text { measure), also a high } \\
\text { proportion of dead branches. } \\
\text { Conflicting data: crown } \\
\text { density. }\end{array}$ & $79(12)$ & 487 (73) \\
\hline $\begin{array}{l}\text { Smicrornis } \\
\text { brevirostris } \\
\text { (weebill) }\end{array}$ & $8.5-9.5$ & Insectivore & $\begin{array}{l}\text { Foliage (high } \\
\text { in the } \\
\text { canopy) }\end{array}$ & $\begin{array}{l}\text { Epicormic } \\
\text { growth }\end{array}$ & $\begin{array}{l}\text { Trees with proportionally larger, } \\
\text { dense canopy, but with dead } \\
\text { branches present in the canopy. }\end{array}$ & $27^{\mathrm{A}}$ & $164(31)$ \\
\hline
\end{tabular}




\begin{tabular}{|c|c|c|c|c|c|c|c|}
\hline $\begin{array}{l}\text { Climacteris rufa } \\
\text { (rufous treecreeper) }\end{array}$ & 15-17 & Insectivore & $\begin{array}{l}\text { Dead } \\
\text { branches, } \\
\text { wood } \\
\text { and/or bark }\end{array}$ & $\begin{array}{l}\text { Proportion of } \\
\text { dead } \\
\text { branches, } \\
\text { crown } \\
\text { dieback }\end{array}$ & $\begin{array}{l}\text { Taller trees with proportionally } \\
\text { larger, dense canopy, with little } \\
\text { epicormic growth but dead } \\
\text { branches present in the canopy. }\end{array}$ & $2^{\mathrm{A}}$ & $150(16)$ \\
\hline
\end{tabular}

${ }^{\mathrm{A}}$ Insufficient data for statistical analyses - observations completed on too few trees to allow distinction of habitat preferences.

\section{Table 2. Tree condition characteristics measured on all trees (site, unused and selected trees)}

All tree condition measures were completed at an approximate distance of half the height of the tree in question. These assessments were conducted twice on each tree at $90^{\circ}$ from each other. In addition to these independent measures of tree characteristics, the continuous variables were incorporated together as a single measure by Principal Components Analysis (PCA) for each tree. The dimensions of these analyses captured a holistic measure of tree health; correlations with these dimensions are show for each variable included $(r)$. The Grimes and Whitford tree condition measures were not included as they were highly correlated with other tree characteristics in the analysis

\begin{tabular}{|c|c|c|c|}
\hline Tree characteristic & Definition & PCA $1^{\mathrm{A}}$ & PCA $2^{\mathrm{B}}$ \\
\hline $\begin{array}{l}\text { Whitford tree condition } \\
\text { measure }\end{array}$ & $\begin{array}{l}\text { Measures overall tree condition on a scale from C1 to C6, where } \\
\text { C1 is healthy crown and C6 is a dead tree. This measure captures } \\
\text { epicormic growth, crown density and crown dieback (Whitford } \\
\text { et al. 2008). }\end{array}$ & 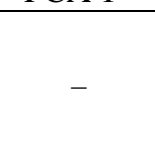 & - \\
\hline $\begin{array}{l}\text { Grimes tree condition } \\
\text { measure }\end{array}$ & $\begin{array}{l}\text { Measures overall tree condition on a scale from } 0 \text { to } 5 \text { where } 0 \text { is a } \\
\text { dead tree and } 5 \text { is a healthy tree with a complete canopy. This } \\
\text { measure captures epicormic growth, crown density and crown } \\
\text { dieback (Grimes 1987). }\end{array}$ & - & - \\
\hline Crown density (\%) & $\begin{array}{l}\text { Percentage of crown containing foliage, branches, and reproductive } \\
\text { structures (Schomaker et al. 2007). }\end{array}$ & $r=-0.499$ & $r=-0.513$ \\
\hline Crown dieback (\%) & $\begin{array}{l}\text { Percentage of crown that has undergone recent dieback, often an } \\
\text { early indication of stress (Schomaker et al. 2007). }\end{array}$ & $r=0.799$ & $r=0.141$ \\
\hline $\begin{array}{l}\text { Uncompacted live } \\
\text { crown ratio (\%) }\end{array}$ & $\begin{array}{l}\text { Ratio of live crown length to above-ground tree length. } \\
\text { Uncompacted means crown length is not reduced to compensate } \\
\text { for gaps between base of live crown and live top of the tree. }\end{array}$ & $r=-0.056$ & $r=0.895$ \\
\hline Epicormic growth (\%) & $\begin{array}{l}\text { Percentage of epicormic growth (growth from buds beneath the } \\
\text { bark) observed in canopy (Podger 1980; Stone 1999). }\end{array}$ & $r=0.781$ & $r=-0.074$ \\
\hline $\begin{array}{l}\text { Proportion of dead } \\
\text { branches (\%) }\end{array}$ & $\begin{array}{l}\text { Percentage of all major branches (diameter }>20 \mathrm{~cm} \text {; counted for the } \\
\text { whole tree) that are senescent. }\end{array}$ & $r=0.810$ & $r=0.160$ \\
\hline Canopy height (m) & $\begin{array}{l}\text { Highest point of tree that is live. Completed three times and } \\
\text { averaged. }\end{array}$ & - & - \\
\hline Leaf litter cover (\%) & $\begin{array}{l}\text { Recorded at the base of each tree (site and selected trees) as close } \\
\text { as possible to the trunk for two } 1-\mathrm{m}^{2} \text { quadrats and averaged to } \\
\text { create a value per tree. Greater litter cover could reflect greater } \\
\text { canopy size or declining health. }\end{array}$ & - & - \\
\hline
\end{tabular}

${ }^{\mathrm{A}}$ For PCA 1 , eigenvalue $=2.231, \%$ of total variance $=44.62$.

${ }^{\mathrm{B}}$ For PCA 2, eigenvalue $=0.996, \%$ of total variance $=19.92$.

Table 3. Logistic regression (negative binominal) describing the differences between trees that were either not observed as being used as foraging resources ('unused' trees) or used by weebills (Smicrornis brevirostris), rufous treecreepers (Climacteris rufa) or yellow-plumed honeyeaters (Lichenostomus ornatus)

The surveys were carried out using two methods (the 'sitting' and 'following' methods; see text for description) at 20 sites in Dryandra State Forest and Wandoo National Park, Western Australia ( $n=$ number of observations made using each method). A total of 211 models were created and assessed by 
Publisher: CSIRO; Journal: ZO:Australian Journal of Zoology

Article Type: research-article; Volume: ; Issue: ; Article ID: ZO13045

DOI: 10.1071/ZO13045; TOC Head:

Akaike Information Criterion (AIC) for each dependent variable; only models with $\Delta \mathrm{AIC}_{\mathrm{c}}<2$ are

shown. For each independent variable used in each model, the standardised $\beta$ coefficient and $P$ values are shown. For each model, the adjusted $R^{2}$ value demonstrates the explanatory power of each model and the $w_{\mathrm{i}}$ indicates the weight of evidence that these models, of all 233 models created for each dependent variable, was the best fit of the data. The log-likelihood statistic (LLc), the fit of each model and d.f. are shown for each model. Whitford tree condition measure, crown density, and tree litter cover were not included in the top models used to describe foraging activities of these bird species

\begin{tabular}{|c|c|c|c|c|}
\hline \multirow[b]{2}{*}{ Method } & \multicolumn{2}{|c|}{ Yellow-plumed honeyeater } & \multirow{2}{*}{$\frac{\text { Weebill }}{\text { 'Following' }}$} & \multirow{2}{*}{$\begin{array}{c}\text { Rufous treecreeper } \\
\text { 'Following' }\end{array}$} \\
\hline & 'Sitting' & 'Following' & & \\
\hline & $\begin{array}{c}n=79 \text { observations } \\
n=12 \text { used trees }\end{array}$ & $\begin{array}{l}n=487 \text { observations } \\
n=73 \text { selected trees }\end{array}$ & $\begin{array}{l}n=164 \text { observations } \\
n=31 \text { selected trees }\end{array}$ & $\begin{aligned} n & =150 \text { observations } \\
n & =16 \text { selected trees }\end{aligned}$ \\
\hline \multicolumn{5}{|l|}{ Factors included in the model } \\
\hline Adjusted $R^{2}$ & 0.044 & 0.065 & 0.174 & 0.463 \\
\hline Grimes tree condition measure & $-0.17(0.01)$ & - & - & - \\
\hline Canopy height & $-0.14(0.05)$ & $0.19(0.00)$ & $0.21(0.00)$ & $0.35(0.00)$ \\
\hline Crown dieback & - & $-0.25(0.00)$ & $-0.07(0.40)$ & $-0.09(0.13)$ \\
\hline Uncompacted live crown ratio & - & $0.12(0.00)$ & $0.33(0.00)$ & $0.44(0.00)$ \\
\hline Proportion of dead branches & & $0.07(0.24)$ & $0.17(0.03)$ & $0.28(0.00)$ \\
\hline Epicormic growth & - & $0.06(0.39)$ & $0.05(0.59)$ & $-0.07(0.12)$ \\
\hline$w_{\mathrm{i}}$ & 0.99 & 1 & 1 & 1 \\
\hline LLc & -118.31 & -273.68 & -152.74 & -100.89 \\
\hline d.f. & 3 & 7 & 7 & 7 \\
\hline
\end{tabular}

